\title{
PLM in the Food Industry: an Explorative Empirical Research in the Italian Market
}

\author{
Claudia Pinna ${ }^{1}$, Marco Taisch $^{1}$, Sergio Terzi ${ }^{1}$ \\ ${ }^{1}$ Politecnico di Milano, Department of Management, Economics and Industrial \\ Engineering Piazza Leonardo da Vinci, 20133, Milan, Italy \\ claudia.pinna@polimi.it \\ marco.taisch@polimi.it \\ sergio.terzi@polimi.it
}

\begin{abstract}
The Food and Beverage (F\&B) industry has a unique role in all countries' economies because it is essential to people lives. In this paper, the focus will be on the Italian food industry, one of the main food producer. This study will present the first results of a wider research that has as main aim to understand how PLM is adopted in the food industry, its limits and its challenges. Indeed, the first results show the level of knowledge of PLM systems in this sector, both from the literature and from the market point of view. Furthermore, the paper shows the results of a preliminary empirical research, made through several case studies, on the role of PLM in the product development process of the food industry.
\end{abstract}

Keywords: New Product Development (NPD), Product Lifecycle Management (PLM), Food Industry, New Food Development (NFD), PLM for the Food Industry

\section{Introduction: the Importance of the Food Sector}

The Food and Bevereage $(F \& B)$ industry has a unique role in all countries' economies because it is essential to people lives. The industry works at various levels of society: there may be families that grow crops and so be self-sufficient, communities producing home-processed goods, local companies transforming crops from families for local markets, and international corporation globally delivering products across the globe. In this scenario, billions of people transform and sell food. [1] The food sector in Europe is the largest manufacturing sector in terms of value added, turnover and employment. It was also the second greatest sector for production between 2008 and 2013. In this paper, Italian food companies will be the boundaries of the analysis because the food industry is a pillar for the economy of this country. Indeed, this sector represents the second sector by revenue after the engineering industry. Companies in F\&B industry face many challenges in managing their products and competing in the industry. According to Oracle [2], Siemens [3] and 
Kalypso [4], the F\&B industry has to contend with different challenges, most of which are referred to: (i) Retail consolidation, (ii) Ineffective innovation, (iii) Increasing regulatory requirements and unclear regulations, (iv) Empowered consumers, (v) Increasingly complex global supply chains, (vi) Sustainability, (vii) Time to Market. Most of these challenges make reference to the need for change in the vision of the food product, from the company point of view. In order to remain competitive in the market, companies operating in this sector must be able to respond promptly to the continuous market and legislation changes. For these reasons, this paper focuses on the specific phase of the New Product Development (NPD) in the food sector, being the one with the highest relevance and that would mainly help this sector to deal with these challenges. This paper starts from a literature review about the level of knowledge of PLM in the food industry (session 2). In this session, the vendors of PLM of the food industry are identified, mapping the main software categories offered by each vendor. Then, in session 3 , the results of an empirical research conducted among some of the main Italian food companies are reported. Finally, session 4 concludes the paper, preseting some thoughts and future researches.

\section{$2 \quad$ PLM and the Food Industry}

All the challenges above mentioned can be well faced using methodologies and tools that allow keeping information consistent and together, make teams work globally, facilitate new product ideas, product portfolio, allow the simplification of packaging and recipe specifications, managing manufacturing planning and supply chain information. In fact, an integrated product lifecycle management (PLM) solution can streamline and improve the fundamental processes that influence the development, launch and ongoing management of products. Such solutions make it possible for food and beverage companies to accelerate innovation, increase profits from product introductions, reduce risks, and ultimately drive competitive advantage.[2]

\subsection{Literature Analysis: the Level of Knowledge of PLM in the Food Industry}

This paper aims to discuss the first steps and results related to a wider research. Regarding the first phase of the research, it concerns to analyse the level of knowledge of PLM systems in the food sector from the literature point of view. It was decided to begin the literature analysis starting from those journals that have a higher rating. Regarding data sources for the review, chosen key words have been applied (product lifecycle management, computer aided, information system) to retrieve the articles of interest in the category "Food Science", which resulted in 61 academic journals. In this elaborate will be treated the first results, characterized by the "product lifecycle management" keyword. Starting from this point, it has been collected 49 articles and, after a careful screening, only 20 studies remained in the final selection of articles. Analysing the results of this first search, the fact that, in the first search, on over 61 journals only 49 articles were found and only 20 were 
considered as interesting could mean a lack level of knowledge of the PLM system in the field analysed. There are in the literature several contributions dealing with themes related to the different phases of the product life cycle (according to Kiritsis [5], the product lifecycle can be defined by three main phases: Beginning of Life, Middle of Life and End of Life), analysed separately, and how the concepts or meanings of each phase have been evolved over time but it is never cited the PLM term. It is also true that the term "product lifecycle management" is a very broad topic. [6][7] Indeed, considering the entire life cycle of the product, the PLM term is not often used as a unique term but it is more common to find other terms that indicate one of its specific phase, a specific method or the software names used in the different stages. In conclusion it could be said that the level of knowledge of the PLM systems is still low in the food sector from the literature point of view but there are different needs in the food sector that could be addressing through the implementation of the PLM systems.

\subsection{PLM Vendors of the Food Industry}

A very important phase of a PLM project is the implementation phase of these systems into the company. In this stage, the choice of PLM software is fundamental in order to get all the benefits from the implemented solution. Therefore, making an assessment of PLM vendors is a good strategy that leads to understand which solution fits better for each specific company. Given the importance of the decision, it is important to have an overview of the main PLM vendors on the market operating in food sector. According to Gartner [8], the major PLM vendors operating in food sector, in terms of market share and offered solutions, are: Dassault Systèmes [9], Infor [10], Oracle [11], SAP [12], Selerant [13], Siemens [14] and Trace One [15]. In 2012 Gartner rated 23 categories of PLM functionality for these seven vendors. These features were then evaluated on the basis of the more fundamental PLM needs of process manufacturers, giving origin to 9 software categories. [8] According to Gartner [16], it is possible to give some definitions of these categories:

(i) $C A D$ design management includes software in support to design data management;

(ii) CAD for packaging design refers to software for packaging design, with for example tools designed for packaging professionals for structural design, product development, virtual prototyping and manufacturing;

(iii) Formula and recipe management includes software for formula or recipe calculation and validation for process manufacturers;

(iv) Label and artwork management refers to software that helps manufacturers develop labels and artwork for different markets that conform to market preferences and regulations;

(v) PLM team collaboration supports tools to collaboration among team members, enabling the facilitation, automation, and control of the entire development process;

(vi) Product portfolio and program management supports the continuous cultivation of product sets by prioritizing and managing product development 
and retirements;

(vii) Report specific to the industry supports tools for monitoring and developing report for specific industry sector;

(viii) Product specifications technology captures the descriptions and quantities of ingredients, materials and other content, including process information needed to produce, package and ship a product;

(ix) Regulatory compliance supports tools that enabling companies to identify what regulations, policies and obligations are applicable to them.

The table below, inspired by Gartner [8], shows the Software Categories offered by each of these vendors.

Table 1. Software Categories offered by main PLM vendors operating in the food sector [9][15]

\begin{tabular}{|c|c|c|c|c|c|c|c|}
\hline $\begin{array}{l}\text { Software Category/ } \\
\text { Vendor }\end{array}$ & $\begin{array}{l}\text { Dassault } \\
\text { Systèmes }\end{array}$ & Infor & Oracle & SAP & Selerant & Siemens & $\begin{array}{l}\text { Trace } \\
\text { One }\end{array}$ \\
\hline $\begin{array}{l}\text { CAD design } \\
\text { management }\end{array}$ & $\mathrm{x}$ & & $\mathrm{x}$ & $\mathrm{x}$ & & $\mathrm{x}$ & \\
\hline $\begin{array}{l}\text { CAD for packaging } \\
\text { design }\end{array}$ & $\mathrm{x}$ & & & & & $\mathrm{x}$ & \\
\hline $\begin{array}{l}\text { Formula and recipe } \\
\text { management }\end{array}$ & $\mathrm{x}$ & $\mathrm{x}$ & $\mathrm{x}$ & $\mathrm{x}$ & $\mathrm{x}$ & $\mathrm{x}$ & $\mathrm{x}$ \\
\hline Label management & $\mathrm{x}$ & $\mathrm{x}$ & $\mathrm{x}$ & $\mathrm{x}$ & $\mathrm{x}$ & $\mathrm{x}$ & $\mathrm{x}$ \\
\hline PLM team collaboration & $\mathrm{x}$ & $\mathrm{x}$ & $\mathrm{x}$ & $\mathrm{x}$ & $\mathrm{x}$ & $\mathrm{x}$ & $\mathrm{x}$ \\
\hline $\begin{array}{l}\text { Product portfolio and } \\
\text { program management }\end{array}$ & $\mathrm{x}$ & $\mathrm{x}$ & $\mathrm{x}$ & $\mathrm{x}$ & $\mathrm{x}$ & $\mathrm{x}$ & $\mathrm{x}$ \\
\hline $\begin{array}{l}\text { Report specific to the } \\
\text { industry }\end{array}$ & $\mathrm{x}$ & $\mathrm{x}$ & $\mathrm{x}$ & $\mathrm{x}$ & $\mathrm{x}$ & $\mathrm{x}$ & $\mathrm{x}$ \\
\hline Regulatory compliance & $\mathrm{x}$ & $\mathrm{x}$ & $\mathrm{x}$ & $\mathrm{x}$ & $\mathrm{x}$ & $\mathrm{x}$ & $\mathrm{x}$ \\
\hline $\begin{array}{l}\text { Specifications } \\
\text { management }\end{array}$ & $\mathrm{x}$ & $\mathrm{x}$ & $\mathrm{x}$ & $\mathrm{x}$ & $\mathrm{X}$ & $\mathrm{x}$ & $\mathrm{x}$ \\
\hline
\end{tabular}

There are also other vendors in the PLM market which offer specific solutions for the food industry. In the table below are shown the PLM categories offered by these other PLM vendors to the food industry.

Table 2. Software Categories offered by other PLM vendors operating in food sector [17][23]

\begin{tabular}{|c|c|c|c|c|c|c|c|}
\hline $\begin{array}{l}\text { Software } \\
\text { Category/ } \\
\text { Vendor }\end{array}$ & Sopheon & beCPG & Aras & $\begin{array}{l}\text { Technia } \\
\text { Transcat }\end{array}$ & Parallaksis & LASCOM & $\begin{array}{l}\text { Advanced } \\
\text { Software } \\
\text { Designs }\end{array}$ \\
\hline \multicolumn{8}{|l|}{$\begin{array}{l}\text { CAD design } \\
\text { management }\end{array}$} \\
\hline \multicolumn{8}{|l|}{$\begin{array}{l}\text { CAD for } \\
\text { packaging } \\
\text { design }\end{array}$} \\
\hline Formula and & & $\mathrm{x}$ & & $\mathrm{x}$ & $\mathrm{x}$ & $\mathrm{x}$ & $\mathrm{x}$ \\
\hline
\end{tabular}




\begin{tabular}{|c|c|c|c|c|c|c|c|}
\hline $\begin{array}{l}\text { recipe } \\
\text { management }\end{array}$ & & & & & & & \\
\hline $\begin{array}{l}\text { Label } \\
\text { management }\end{array}$ & & $\mathrm{x}$ & & $\mathrm{x}$ & $\mathrm{x}$ & $\mathrm{x}$ & $\mathrm{x}$ \\
\hline $\begin{array}{l}\text { PLM team } \\
\text { collaboration }\end{array}$ & $\mathrm{x}$ & & & $\mathrm{x}$ & & & \\
\hline $\begin{array}{l}\text { Product } \\
\text { portfolio and } \\
\text { program } \\
\text { management }\end{array}$ & $\mathrm{x}$ & $\mathrm{x}$ & $\mathrm{x}$ & $\mathrm{x}$ & & $\mathrm{x}$ & $\mathrm{x}$ \\
\hline $\begin{array}{l}\text { Report specific } \\
\text { to the industry }\end{array}$ & & $\mathrm{x}$ & $\mathrm{x}$ & $\mathrm{x}$ & $\mathrm{X}$ & & $\mathrm{x}$ \\
\hline $\begin{array}{l}\text { Regulatory } \\
\text { compliance }\end{array}$ & $\mathrm{x}$ & $\mathrm{x}$ & & $\mathrm{x}$ & $\mathrm{X}$ & $\mathrm{x}$ & \\
\hline $\begin{array}{l}\text { Specifications } \\
\text { management }\end{array}$ & & $\mathrm{x}$ & $\mathrm{x}$ & $\mathrm{x}$ & $\mathrm{X}$ & $\mathrm{X}$ & \\
\hline
\end{tabular}

\section{A Preliminary Empirical Research}

In order to better understand how the use of PLM systems could enhance the performances related to the different phases of the NPD in food industry, it is necessary to know how these processes happen. Given the absence of this information in the scientific literature it was decided to obtain them through an empirical research, interviewing some of the main Italian food companies. It has therefore developed a questionnaire consisting of 11 open questions. These questions are also related to the actors participating in this process, the kind of performances considered important for the food NPD, and the forces (internal and external) that lead to the decision to develop a new product and how long lasts this process (from concept to the launch stages). The questionnaire was designed to be subjected to those business functions that deal directly the innovation and the development of the new product, and thus the functions engaged in R\&D and Marketing areas and then submitted in the form of interview to 10 different Italian large companies operating in food industry. Interviews were registered and answers were coded in a standard format, aligning terminology and concepts. In order to describe the product development process, 5 different "macro phases" have been defined, assigning a cardinality from 0 to 5 depending on the assigned sequentially. Moreover, each of these "macro phases" are characterized by various activities, which can change depending on the interviewed company. After these previous and necessary data adjustment, it was possible to analyse the clean data, obtaining the following result:

Table 3. New Product Development main activities in food industry

\begin{tabular}{ccc}
\hline Macro Phase & \multicolumn{1}{c}{ Activities } \\
\hline 0 & Planning & Concept Generation \\
\hline
\end{tabular}




\begin{tabular}{cccc}
\hline 1 & $\begin{array}{c}\text { Idea Internal } \\
\text { feasibility }\end{array}$ & Recipe development & Recipe Internal feasibility \\
\hline 2 & Prototyping & $\begin{array}{c}\text { Product Internal } \\
\text { feasibility }\end{array}$ & $\begin{array}{c}\text { Product External } \\
\text { feasibility }\end{array}$ \\
\hline 3 & Industrialization & & \\
\hline 4 & $\begin{array}{c}\text { Production Rump- } \\
\text { Up }\end{array}$ & & \\
\hline
\end{tabular}

The Table 3 summarize the main questionnaire results listing the phases that characterize the food new product development, obtained through the company interviews. As can be inferred from this table, to each macro phase corresponds one or more activities that need to be developed in order to skip to the next macro phase. In fact, from the results of the interviews it is also possible to deduce that a NPD process, in food industry, is a process characterized by different macro phases, in turn characterized by more activities, which are carried out in a sequential manner. Thanks to the interviews analysis it can also be said that, compared to the sample studied, the companies operating in the food sector use the Stage and Gate model in order to organize the NPD process.

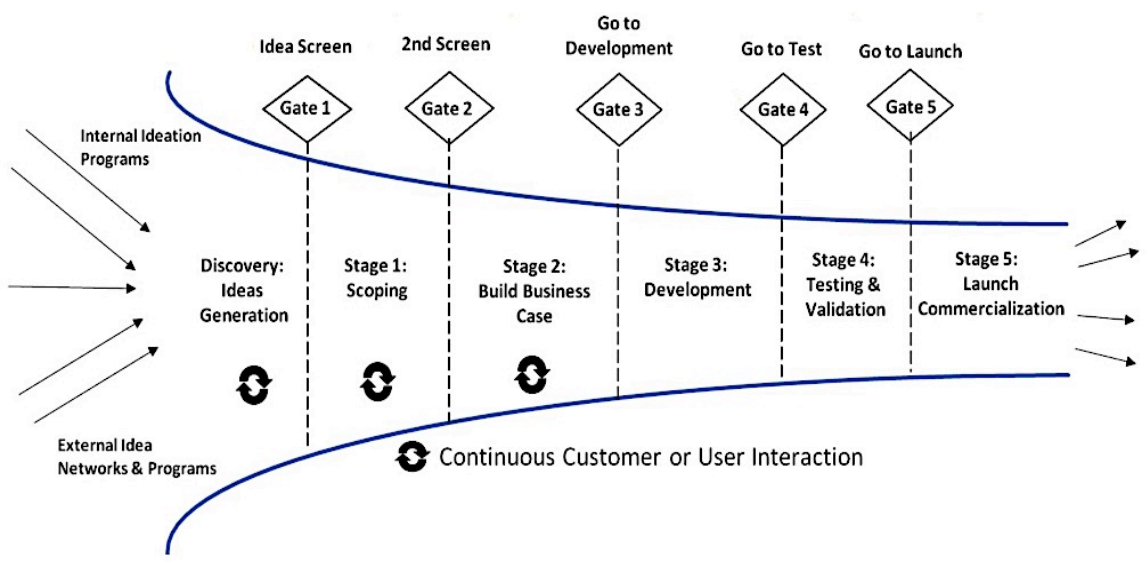

Fig. 1. A Typical Stage-Gate Process [24]

The elaborations of the questionnaire responses showed also other important results. First of all, the analysis of the questionnaire shows that the internal and external forces that push a food company to develop a new product are related to: (i) the customers (with their always changing needs), (ii) the marketing staff of the company (following their market analysis), (iii) the sales staff of the company and (iv) the regulatory compliance (refers to the country where the company sells or want to sell their products). In addition, these analyses also showed that the food NPD process is a collaborative process, characterized by the collaboration of most business functions that cooperate to each other. In particular, the results indicate that the business functions that mainly contribute to the food NPD process are: Research and 
Development, Marketing, Production, Quality and Engineering. In the questionnaire, two different categories of new product are taken into account, mainly related to the level of novelty of the product. Therefore, it will be referred to "radically new products" (not existing before in the company) and "improved products" (already existing in the company and incrementally improved over the time). These results disclose that (on average) 18 months are needed for the development of radically new products while 12 months for those that have to be improved. Other results are related to the factors that are considered fundamental for the new recipe development. In fact, when a food company decides to create a new recipe there are some factors that influence and that have to be taken into consideration in the NPD process. These important factors, listed in order of importance, are: quality, cost, customer satisfaction and Time to Market (TTM). The definition of these important factors have been previously defined, in order to support the person interviewed. Regarding the definition of quality, according to Grunert [25], it can be said that a product is a quality product "only when producers can translate consumer wishes into physical product characteristics, and only when consumers can then infer desired qualities from the way the product has been built." The cost instead refers to the total cost to be incurred for the NPD (considering all the resources necessary for this process realisation). According to Kotler [26], "customer satisfaction (or dissatisfaction) can be defined as the customer's perception of a product's qualities matching (or failing) their preconceived expectations" while the Time to Market (TTM) is defined as "time elapsed from the beginning of the planning horizon until the firm releases the new product for sale in the market" [27]. In addition, the analysis of the questionnaire shows that most of the companies interviewed are not familiar with the main methodologies generally used along the NPD phase. According to Terzi there are a lot of methodologies that should be used in the PLM framework according to the different needs of the various phases of product lifecycle [28]. The main aim of this section of the questionnaire is to understand the level of use and of knowledge of the different methodologies in the NPD phase. In particular these methodologies are: theory for inventing problem solving (TRIZ) [29], quality function deployment QFD [30], value analysis and engineering VA\&E [31], design to cost and target cost management DTC/TCM [32], robust design and modular design [33], variety reduction program VRP [34] and risk analysis [35]. Going to the specific results, $60 \%$ of companies surveyed do not know any of these methods while some of them use QFD (10\%), Risk Analysis (20\%) and TRIZ (10\%). Furthermore, 60\% of these companies use methodologies ad hoc to support the NPD phase. The interviews also show that only $10 \%$ of the surveyed companies use PLM systems to support this phase. It is also important to note that the sample represents $10 \%$ of the total sample (large Italian food industries). The last question of the questionnaire refers instead to knowledge management. This question is fundamental because allowed to comprehend how the knowledge is managed in food companies, this is important, in fact the knowledge management is a key factor in the new product development and in the implementation of a PLM project. In order to implement KM, it is necessary to be able to manage several sub-processes that nowadays can be easily supported by the different software categories in various systems. In fact, those software categories can 
be implemented within system of different nature (e.g. PDM, ERP, PLM...). In the table below are summarized the results obtained from the last question of the questionnaire showing the level of support of these categories, set out above, on information systems.

Table 4. How systems fulfil PLM requirements in food industry

\begin{tabular}{|c|c|c|c|c|}
\hline $\begin{array}{c}\text { Software } \\
\text { categories }\end{array}$ & \multicolumn{4}{|c|}{ IT systems } \\
\hline Name & No & PDM/PLM & ERP & Other Systems \\
\hline $\begin{array}{l}\text { CAD design } \\
\text { management }\end{array}$ & \multirow{2}{*}{$\begin{array}{l}60 \% \text { do not use } \\
\text { any system to } \\
\text { support these } \\
\text { categories }\end{array}$} & \multirow{2}{*}{$\begin{array}{l}\text { Software } \\
\text { categories not } \\
\text { very requested } \\
\text { for food } \\
\text { companies } \\
(20 \%)\end{array}$} & \multirow{2}{*}{$\begin{array}{l}\text { ERP is not used } \\
\text { there }(0 \%)\end{array}$} & \multirow{2}{*}{$\begin{array}{l}\text { Some companies } \\
\text { use ad hoc } \\
\text { systems to } \\
\text { support the } \\
\text { packaging design }\end{array}$} \\
\hline $\begin{array}{l}\text { CAD for } \\
\text { packaging } \\
\text { design }\end{array}$ & & & & \\
\hline $\begin{array}{l}\text { Formula and } \\
\text { recipe } \\
\text { management }\end{array}$ & \multirow{2}{*}{$\begin{array}{l}\text { Only } 20 \% \text { of } \\
\text { companies do } \\
\text { not use any } \\
\text { system to } \\
\text { support these } \\
\text { functionalities }\end{array}$} & \multirow{2}{*}{$\begin{array}{l}\text { These } \\
\text { functionalities } \\
\text { are the most } \\
\text { used in food } \\
\text { companies in a } \\
\text { PLM system } \\
(40 \%)\end{array}$} & \multirow{2}{*}{$\begin{array}{l}\text { Only } 20 \% \text { use ERP } \\
\text { in Formula and } \\
\text { recipe management } \\
\text { ERP is not used in } \\
\text { Label and } \\
\text { management }(0 \%) \text {. }\end{array}$} & \multirow{2}{*}{$\begin{array}{l}\text { Many } \\
\text { companies rely } \\
\text { on ad hoc } \\
\text { systems }(40 \%)\end{array}$} \\
\hline $\begin{array}{l}\text { Label } \\
\text { management }\end{array}$ & & & & \\
\hline $\begin{array}{l}\text { PLM team } \\
\text { collaboration }\end{array}$ & \multirow{2}{*}{$\begin{array}{l}40 \% \text { of the } \\
\text { interviewed } \\
\text { companies do } \\
\text { not implement } \\
\text { these categories } \\
\text { in any system }\end{array}$} & \multirow{2}{*}{$\begin{array}{l}\text { These } \\
\text { functionalities } \\
\text { are the most } \\
\text { used in food } \\
\text { companies in a } \\
\text { PLM system } \\
(40 \%)\end{array}$} & \multirow[b]{2}{*}{$\begin{array}{l}\text { ERP is not used } \\
\text { there }(0 \%)\end{array}$} & \multirow[b]{2}{*}{$\begin{array}{l}\text { Only } 20 \% \text { of } \\
\text { companies uses } \\
\text { ad hoc systems } \\
\text { for these } \\
\text { functionalities }\end{array}$} \\
\hline $\begin{array}{l}\text { Product } \\
\text { portfolio and } \\
\text { program } \\
\text { management }\end{array}$ & & & & \\
\hline $\begin{array}{l}\text { Report specific } \\
\text { to the industry }\end{array}$ & $\begin{array}{l}40 \% \text { of the } \\
\text { interviewed } \\
\text { companies do } \\
\text { not implement } \\
\text { these categories } \\
\text { in any system }\end{array}$ & $\begin{array}{l}\text { For reporting, } \\
\text { companies still } \\
\text { rely on internal } \\
\text { instruments, not } \\
\text { to PLM }(20 \%)\end{array}$ & $\begin{array}{l}\text { Only } 20 \% \text { use ERP } \\
\text { there }\end{array}$ & $\begin{array}{l}40 \% \text { of } \\
\text { companies use } \\
\text { ad hoc systems } \\
\text { also for specific } \\
\text { reporting }\end{array}$ \\
\hline $\begin{array}{l}\text { Regulatory } \\
\text { compliance }\end{array}$ & $\begin{array}{l}40 \% \text { of the } \\
\text { interviewed } \\
\text { companies do } \\
\text { not implement } \\
\text { these categories } \\
\text { in any system }\end{array}$ & $\begin{array}{l}\text { No company } \\
\text { supports this } \\
\text { category in plm } \\
\text { system }(0 \%)\end{array}$ & $\begin{array}{l}\text { ERP is not used } \\
\text { there }(0 \%)\end{array}$ & $\begin{array}{l}\text { Companies } \\
\text { prefer ad hoc } \\
\text { solutions for } \\
\text { experimented in } \\
\text { their business } \\
(60 \%)\end{array}$ \\
\hline $\begin{array}{l}\text { Specifications } \\
\text { management }\end{array}$ & $\begin{array}{l}\text { All companies } \\
\text { use a system to } \\
\text { manage the } \\
\text { product } \\
\text { specifications } \\
(100 \%)\end{array}$ & $\begin{array}{l}\text { Only } 20 \% \text { of } \\
\text { companies use } \\
\text { this categories } \\
\text { supported in a } \\
\text { PLM system }\end{array}$ & $\begin{array}{l}\text { Only } 20 \% \text { use ERP } \\
\text { there }\end{array}$ & $\begin{array}{l}\text { Companies } \\
\text { prefer ad hoc } \\
\text { solutions for } \\
\text { experimented } \\
\text { in their } \\
\text { business }(60 \%)\end{array}$ \\
\hline
\end{tabular}


As shown in the previous table, most companies use ad hoc systems to support these categories or do not support them at all. Moreover, there are few companies that use PLM systems to support some of these software categories. Starting from these last results, understanding the reason why most of these food companies are not familiar with the methodologies and why they are reluctant to the use of the PLM systems for NPD could be a further step of this research.

\section{Conclusions \& Further Research}

As previously mentioned, according to the first analysis, the topic of PLM in the food sector is not yet widely covered from the literature point of view. Nevertheless, the market offers several PLM solutions for this industry. Indeed, there are many vendors of PLM solutions that offer dedicated and customized solutions for the food industry. As previous said, this industry is an ever-changing industry, which needs in continuous improvements and to be able to meet several challenges. The use of the PLM system could help to meet these challenges and to improve the NPD processes. The analysis of the interviews highlights that the NPD activities in food industry follow a clear process, with well-defined and sequential phases, with different control gates, from the concept generation to the launch stage. Furthermore, the knowledge of these phases and of the relevant performances will support the next steps of this research, consisting in a development of a model that will allow to figure out if the use of PLM solutions can improve the NPD performances. This model could be used by the food company to enabling them to: (i) assess their situation as-is compared to the performances identified, (ii) make benchmarking with other food companies, (iii) understand the areas in which they are weak and in which they must improve and (iv) understand the areas where they are likely to improve.

\section{Acknowledgements}

This work has been funded by the Italian project SMART MANUFACTURING 2020 - CTN01_00163_216744 - Cluster: CFI Fabbrica Intelligente.

\section{References}

[1] M. Pfitzer and R. Krishnaswamy, "The Role of the Food \& Beverage Sector in Expanding Economic Opportunity," p. 44, 2007.

[2] Oracle, "Product Lifecycle Management in the Food and Beverage Industry An White Paper," no. February, 2008.

[3] Siemens, "Siemens PLM Software for food and beverage White Paper," 2011.

[4] Kalypso, "PLM Vivo : Rapid Deployment PLM for Food \& Beverage White Paper," p. $12,2010$.

[5] D. Kiritsis, A. Bufardi, and P. Xirouchakis, "Research issues on product lifecycle 
management and information tracking using smart embedded systems," Adv. Eng. Informatics, vol. 17, no. 3-4, pp. 189-202, 2003.

[6] G. Schuh, H. Rozenfeld, D. Assmus, and E. Zancul, "Process oriented framework to support PLM implementation," Comput. Ind., vol. 59, no. 2-3, pp. 210-218, 2008.

[7] F. Ameri and D. Dutta, "Product lifecycle management: Closing the knowledge loops," Comput. Aided. Des. Appl., vol. 2, no. 5, pp. 577-590, 2005.

[8] K. Findings, "A Guide to PLM Providers for Formulated Packaged Goods Industries," p. 27, 2012.

[9] "Dassault Systèmes." [Online]. Available: http://www.3ds.com/it.

[10] "Infor." [Online]. Available: http://www.infor.com/industries/food-beverage/.

[11] “Oracle." [Online]. Available: http://www.oracle.com/it/index.html.

[12] “SAP." [Online]. Available: http://go.sap.com/italy/index.html.

[13] "Selerant." [Online]. Available: http://www.selerant.com/corp/.

[14] “Siemens." [Online]. Available: https://www.plm.automation.siemens.com/it_it/.

[15] “Trace One." [Online]. Available: http://www.traceone.com/en/.

[16] M. Halpern, S. Jacobson, and J. Suleski, "Hype Cycle for Discrete Manufacturing and PLM, 2014," Gartner, no. July, p. 93, 2014.

[17] “Technia Transcat." [Online]. Available: http://www.techniatranscat.com/techniatranscat.

[18] "Sopheon." [Online]. Available: https://www.sopheon.com/.

[19] "Parallaksis." [Online]. Available: http://www.parallaksis.com/.

[20] "Lascom." [Online]. Available: http://www.lascom.com/.

[21] "beCPG." [Online]. Available: http://www.becpg.net/.

[22] "Aras." [Online]. Available: http://www.aras.com/.

[23] "Advanced Software Designs." [Online]. Available: http://www .asdsoftware.com/.

[24] S. J. Edgett, "Idea - to - Launch ( Stage - Gate ${ }^{\circledR}$ ) Model : An Overview," pp. 1-5, 2015.

[25] K. G. Grunert, "Food quality and safety: Consumer perception and demand," Eur. Rev. Agric. Econ., vol. 32, no. 3, pp. 369-391, 2005.

[26] P. H. C. P. Kotler, K.L. Keller, S. Sivaramakrushnan, Marketing management 14th. Canadian ed. Pearson Education, 2013.

[27] J. E. Carrillo and R. M. Franza, "Investing in product development and production capabilities: The crucial linkage between time-to-market and ramp-up time," Eur. J. Oper. Res., vol. 171, no. 2, pp. 536-556, 2006.

[28] M. Garetti, S. Terzi, N. Bertacci, and M. Brianza, "Organisational change and knowledge management in PLM implementation," Int. J. Prod. Lifecycle Manag., vol. 1, no. 1, p. 43, 2005.

[29] G. S. Altshuller, The Art of Inventing (And Suddenly the Inventor Appeared). Worcester, Massachusetts, MA: Technical Innovation Center, 1994.

[30] Y. Akao, QFD: Quality Function Deployment - Integrating Customer Requirements into Product Design. 2004.

[31] J. J. Kaufman, Value engineering for the practitioner. NC, USA: North Carolina State University Press., 1990.

[32] W. P. Michaels, J.V. and Wood, Design to cost. New Jersey, NJ: Wiley, 1989.

[33] J. Jiao and M. M. Tseng, "Fundamental Issues Regarding Developing Product Family Architecture for Mass Customization," Integr. Manuf. Syst., vol. Vol. 11, no. No. 7, pp. pp.469-483., 2000.

[34] A. Koudate, Il management della progettazione. ISEDI (Translated from Japanese to Italian by R. Manisera and R. Giovannuzzi)., 2003.

[35] J. Stein, A. Massey, and S. Schwartz, Fundamentals of Risk Analysis and Risk Management. 1996. 